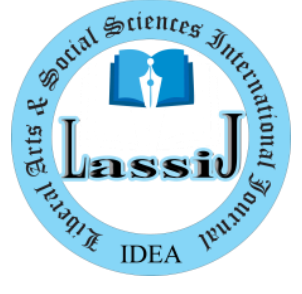

ISSN: 2664-8148 (Online)

Liberal Arts and Social Sciences

International Journal (LASSIJ)

https://doi.org/10.47264/idea.lassij/2.1.6

Vol. 2, No. 1, (January-June) 2018, 49-56

https://www.ideapublishers.org/lassij

\title{
The Bluest Eyes: Objectification of Women and Victimization of Male Sex-offenders
}

\author{
Zenab Jahangir $^{1 *}$, Tayyaba Bashir ${ }^{2}$, and Rasib Mahmood ${ }^{3}$
}

1. Department of English, National University of Modern Languages (NUML), Islamabad, Pakistan.

2. Department of English, International Islamic University Islamabad (IIUI), Islamabad, Pakistan.

3. Department of English, Qurtuba University of Science and Technology, Peshawar, Pakistan.

\begin{abstract}
The present study intends to study Toni Morrison's novel The Bluest Eyes with a Feminist approach. It shows how the sex-offenders oppress little black girls in a patriarchal society. The sexoffenders on the other hand are presented as victims of circumstances and their victimization of black girls is justified by portraying the girls to be the cause of the heinous acts committed to violate their innocence. All black girls, despite the claim of the novelist that it is written from their perspective, are presented in the novel to be reasonably oppressed by the male characters. The author through a series of incidents has tried to depict the objectification of the female sex on one side while the victimization of the sex-offenders on the other. It is a strange dichotomy of events and incidents which has been explored through Catherine Belsey's Textual Analysis as tool of interpreting various scenes and dialogues.
\end{abstract}

Keywords: Incest, Rape, Sex-Offenders, Oppressors, Paedophilia, Victimization, Feminism.

\section{Introduction}

Toni Morrison is an acknowledged Afro-American writer and winner of Nobel Prize for literature in 1993. She is considered as a profound black feminist writer. She is the writer of The Bluest Eyes (1970), Sula (1973), Beloved (1987), The Song of Solomon (1977), Jazz (1992) and God Help the Child (2015). She mainly deals with racism in her literary works and describes the ways in which the black people are oppressed in the white-dominant society, specifically black women. The Bluest Eyes is her debut novel and initially has not been well received by the critics and the readers. However, with passage of time the critics have commended the novel.

In "Foreword" to The Bluest Eyes, Morrison has revealed her intentions for authoring the novel to be encompassing racism present in American society. Furthermore, she has also introduced 
the concept of racial beauty and has emphasized that the Blacks need to accept their own identity (Laksmitarukmi, 2017; Alwan, \& Kadir, 2018; Any, 2016). The study has been limited to Toni Morison's novel The Bluest Eyes. The paper tries to explore new avenues of research in the works of Toni Morrison from different perspectives. The main focus of the paper is to investigate Morison's dealing with racism and propagation of victimized representation of male sex-offenders in her novel The Bluest Eyes.

The present paper aims to analyse the novel from the feminist perspective with special emphasis on the sex offenders in the novel, like Cholly, Henry and Soaphead Church and how they have been presented as victims rather than offenders who exploit the innocence of young black girls. There is no shortage of research data on The Bluest Eyes. However, during wide range of data being analysed vis-à-vis this paper, it has been observed that Morrison being in her initial stages of career has depicted sex-offenders as victimized and oppressed strata of the society. She claims to be a woman-cause advocate but her first novel seemingly deviates from her usual feminist notions.

\section{Literature Review}

The issue of representation has always remained a source of disagreement between those who want to maintain their power, hegemony, and control on social, political, and economic fronts, Looking from this perspective, women have always remained, in one way or the other, oppressed and dominated. They are treated as objects in the male dominated society in every possible aspect. Many a times, they have been blamed even without any reason. This objectification leads to the social dilemma where women are held responsible for every action even if they are having no fault of their own. The Bluest Eyes by Toni Morrison has been discussed from various angles since it holds some rich insights into the human conditions in this world. To situate the present study, it is important to present an overview of the criticism this novel has received.

When one reads the existing literature on this topic, then there is no dearth of research conducted on Morison's novels. The Bluest Eye, for example, has been studied varyingly by different critics and various tendencies instantly become observable in this piece of art Ahlawat (2013), for example, in his article the critic has basically analysed three novels of Morrison, Sula, Beloved and The Bluest Eyes. He has evaluated the novel based on eco-feminist theory and has equated the female characters of the novels with nature. He argues in his article that nature and women both are oppressed in the patriarchal society. He further expands this idea by saying that both the nature and the women in one way or the other try to show resistance to this oppression.

Anju and Sharma (2011) in their paper have studied the persisting themes in the novels of Toni Morrison. They have established violence, oppression and sacrifice as basic themes of her novels. They have also incorporated themes of racism against black communities by the whites 
and as well as oppression of Blacks by the Blacks. Therefore, they have concluded that Morrison has uniquely dealt with the theme of violence in her novels.

Babamiri (2014) in his study has presented a unique perspective on The Bluest Eyes. He argues that Morrison has presented deformed image of motherhood and it is distorted because of racism. He argues that Morrison has tried to depict that due to racism African Americans have lost their selfhood and the distorted motherhood is unable to transfer protection and empowerment to the black children. This leads to psychological trauma among the young black children in the narrative.

Sarulatha and Geetha (2015) have highlighted that Morrison has tried to exhibit identity crisis of black communities in contrast to social and political scenario of America in The Bluest Eyes. The socio-political scene has been set by the white community in the novel and under this net the blacks are treated as inferiors. The young black girl, under the oppressive environment, yearns for the bluest eyes to be accepted by the white-oriented society, and hence suffers from identity crisis.

Heinart (2009) in her essay "Novel of 'Education': Bildungsroman and The Bluest Eye" has asserted that The Bluest Eyes cannot be called as Bildungsroman but rather it is an antiBildungsroman. She gives the evidence by saying that none of the characters show any type of growth since their growth is disrupted by racism at the end.

Mbalia (1991) has claimed in her essay "The Bluest Eye: The Need for Racial Approbation" that Morrison's attitude in the novel is underdeveloped. The writer argues that Morrison being in her early stages of career has considered racism as a major issue in the marginalization of blacks; however, she has ignored the class system of the capitalist society, America, in downgrading of the blacks.

It is in this context that the present study will be an addition to the existing literature on the subject since it looks at the novel from a feminist point of view. In this research, the researchers have tried to highlight the true picture of representation, subjugation, racial discrimination of the female characters by both their local and foreign masters. The black girls suffer psychologically because they face threat, violence, and harassment from both their black counterparts as well as from the white.

\section{Theoretical and Methodological Approach}

The main question of the study is whether Toni Morison is dealing with racism or propagating victimized representation of male sex-offenders in her novel, The Bluest Eyes. Lois Tyson, in Critical Theory Today, argues about feminist criticism that it is presentation of women as, 'oppressed by patriarchy economically, politically, socially, and psychologically' (Tyson, 2006, p. 92). Therefore, the study centres around feminist ideology of suppression and how the 
oppressors are presented as innocent men. For this purpose, Simone de Beauvoir's work "The Second Sex" (1949) has been taken as foundation for the formulation of theoretical framework of the paper.

She considers that women are oppressed not because of their biological construction but rather based on social and historical notions of the society and they are considered as "other." Therefore, they are oppressed socially, physically, psychologically, politically, and economically. Catherine Belsey's Textual Analysis has been employed as research methodology to investigate the primary text. Belsey in her essay "Textual Analysis as a Research Method" (2005) has elucidated that the analysis of a literary text is dependent on the interpretation of literary reader and the impact of text on him/her. It is vital in the analysis for the present study as it takes into consideration the secondary sources but mostly it focuses on the interpretation of the text. Belsey's method is more open-ended and it gives opportunity to the researcher to analyse the work from his/her perspective.

\section{Discussion and Findings}

The Bluest Eyes being Morrison's (1970) first novel is lacking in many aspects as evident in the essay of Doreatha Drummond Mbalia. Morrison has claimed in the "Afterword" of the novel that she has tried to reveal the story, 'from the vintage point of the victims or could-be victims of rape - the person no one inquired of; the girls themselves' (Morrison, p. 210). Furthermore, she also states in the same section that her major interest in the novel has been, '...the reclamation of racial beauty' (Morrison, p. 206), and for her it is not a response to selfdeprecating, idiosyncrasies as are to be found among the individuals of different types races and cultures who have been subjected to such treatment as the Afro-American people have been. For her, it is a reaction to the unending sense of inferiority that is continuously triggered by the way the outside world sees the race (Morrison, p. 206). However, despite her obvious assertion that she has tried to depict racism and its impacts on the little girls in doing, she has presented the culprits as the victims and vice versa. Therefore, the study intends to explore the reversal of the status from the sex-offenders to the victims of the "racial self-contempt" (Morrison, p. x).

\subsection{Portrayal of Podophiles in The Bluest Eyes}

There are numerous examples in the text where one can find paedophiles in the shape of Henry Washington and Soaphead Church. However, these paedophiles are presented as if they are under compulsion to do so and the little girls are the ones who should be held responsible for this heinous act.

The readers are introduced with Henry Washington as to be roomer in the Mactrees' house. He is having, "small even teeth with a friendly gap in the middle" (Morrison, p. 13), and, according to medieval physiognomy, it is a sign of licentiousness. He is presented as a religious and 
humble person who is tender hearted and benevolent towards the kids. It is alluded by Claudia that despite his abuse of Frieda, the girls, Frieda and Claudia, are not having any harsh feelings for him.

As Claudia remarks it, 'We loved him. Even after what came later, there was no bitterness in our memory of him' (Morrison, p. 14). The little girls, Frieda and Claudia, are presented by Morrison as if they themselves wanted to be molested by men. Morrison has shown that the little girls are longing for the touch of a man as said by Claudia, 'I looked forward to the delicious time when "my man" would leave me' (Morrison, p. 24). The little girls are not shown as innocent and unaware of their sexuality but rather completely aware of it. For instance, Claudia equates the "white spots" on her fingernails as "the number of boyfriends" she would have (Morrison, p. 25). Another example of this consciousness is when Frieda associates the menstruation of Pecola with a possibility to "have a baby" (Morrison, p. 26).

Therefore, Morrison has shaped the mindset of the reader that if whatever happens, the little girls will be having a hand in it. That is why when the reader comes to know about molestation of Frieda by Henry, Claudia is excited to know about the incident. She inquires Freida, "Really? How did it feel?" (Morrison, p. 97) and then further asks, "But wasn't it supposed to? Feel good, I mean?" (Morrison, p. 97). She longs for the same fondling as is evident from the way she explores her chest and feels blue over finding it not worth a pinch. Freida says to her that it is just the jealous talk and that is why she wants him to do the same to her. She responds to Frieda that she is not jealous; it is just that she has had enough of being the last to get everything (Morrison, p. 98). Morrison shows the teenage frustration to explore and discover, among many other things, the sexual changes occurring in the body. It, subsequently, raises the suspicion about Freida's role in that groping business.

Thus, the reader is left utterly befuddled whether Henry was solely responsible for the act or Frieda as well had a say in it. Therefore, a reader finds it hard to sympathize with the victim, Frieda, rather suspect her for having consent in it. It is evident through research studies that child abuse has long term psychological consequences on the affectee. However, in this novel the abuse is rather presented as consensual activity where the little girls are shown to have yearning for it.

Soaphead Church or Elihue Micah Whitcomb, a paedophile, who in the name of religion, plays with common people. It is said about his business in the novel: His business was dread. People came to him in dread, whispered in dread, wept, and pleaded in dread. And dread was what he counselled (Morrison, p. 170). He accepts his identity being a paedophile but provides justifications for it and believes that "Evil existed because God had created it" (Morrison, p. 170). He provides reasons for him being a paedophile and Morrison has tried to display him as one who due to his past experiences with a woman, Velma, has turned to be so. However, it seems unreasonable for little girls to go into his business and seek his counsel and let him play with them. 
Soaphead expresses in his letter to God his unusual experience with little girls. He expresses his bewilderment over the thought of his death and question that why he would have to die since he has always been kind. He, then, states that he is only going to miss small girls and goes about describing the details about his obscene activities with little girls. He describes the way he gave those little girls money or treats or ice-cream that they enjoyed while he kept playing with their open legs. He describes it as a friendly party with little girls and claims that they kept coming back because they enjoyed it, and therefore he was not hurting them as the newspapers said or people whispered (Morrison, p. 179).

In very explicit and rather obscene terms the writer has depicted that the little girls, Frieda and Claudia, have been "friendly" with Soaphead. His crime despite being atrocious is labelled as a reaction against his former relation with Velma, his ex-wife. Here one can find more victimization of sex-offenders than racism and rationalization for child oppression. Morrison despite her claim that she has written the novel from the perspective of racism has implicitly blamed little girls instead of presenting them as victims of paedophilia; the podophiles on the other hand are justified for oppressing the little girls both physically and psychologically. Hence, as Mbalia has argued in her essay that Morrison is unable to defend her claim that she has authored a story of "racial self-contempt."

\subsection{Incest/Rape as Instrument of Objectification in The Bluest Eyes}

The Breedloves: Pauline, Sammy and Pecola, are depicted as ugly characters and their ugliness is because of some inherent guilt of theirs: You looked at them and wondered why they were so ugly; you looked closely and could not find the source. Then you realized that it came from conviction, their conviction (Morrison, p. 37).

Pecola Breedlove one of the major characters of the novel is regarded as the ugliest girl, even at her birth her mother remarks about her that, "head full of pretty hair, but Lord she was ugly" (Morrison, p. 124). Therefore, one can find loneliness in her character and a longing for recognition, sympathy, and companionship. She uses her ugliness as a mask to hide behind it. Cholly Breedlove, Pecola's father, on the other hand is not ugly in his appearance but rather in his deeds.

Pecola has always been in search to find out the cause of her ugliness which has caused her to be neglected and scorned by others, "but she has seen interest, disgust, even anger in grown male eyes" (Morrison, 1970, p. 47). On the other side, Cholly being an unbridled has not been under any obligation or responsibility because he has been abandoned by his father before birth and his mother also throws him on a garbage dump. He directs his anger and frustration towards other characters in the novel, for instance he encounters two white men while he was making love with the Darlene and he unleashes his hatred and shame on the Darlene rather than on the white men. However, Pecola only endures whatever has been directed at her without raising any complaint. 
The boundary between rape and incest has been blurred by Morrison as it is left questionable whether it was a rape or incest. For the reason that Pecola has been shown as yearning madly for recognition and companionship while Cholly on the other hand has been shown as if he wants to provide his daughter with the missing vacuum in her life. The novel seems to be justifying Cholly's action of raping his daughter. Morrison portrays him in a way that he seems to be incapable of expressing his love for his daughter in any other way possible than raping her. The reason given for the incestuous act, is Cholly's inability to express his emotions in an alternative way. She describes him to be having "befuddled brain" and incapable of looking his daughter in the eye to accept her love or to return it or to make her smile. Thus, Cholly is depicted in justifying tone: Morrison seems to rationalize his act of bending down his daughter and raping her, as it was the only way for him to express himself (Morrison, pp. 159-60).

One can suspect the scene either an instance of rape or incest, Pecola yearning for love and Cholly wants to make his daughter happy. However, in both cases Pecola is to be blamed for her father's advances towards her. Although being only eleven years old, after the incident the hatred of community is directed towards her. Instead of sympathy, the black community loathes her to be impregnated by her own father. Whereas Cholly only suffers exile but Pecola suffers all the hardships.

\section{Conclusion}

The analysis of major themes reveal that despite obvious declaration of the novelist in the "Foreword" and "Afterword" of the novel that she has tried to depict 'racial self-contempt' of black children has conversely presented the abusers of black girls as victimized. On the other hand, the black girls are shown as to be the cause of the abuse rather than the receiver of the abuse which has been aimed at them. Hence, it proves the constructed biasness towards female gender especially in scenario of black communities. They are considered the cause of all disturbances even if they are the ones who are disturbed. The stance has not been only supported theoretically but incidents in the novel also support the assertion that the male sexoffenders have been represented as victims rather than the convicts.

\section{References}

Ahlawat, A. (2013). Eco-feminist study of Toni Morrison's novels: The Bluest Eye, Sula and Beloved. International Journal of Humanities and Social Science Invention, 2(8), 5658.

Alwan, R. M., \& Kadir, Z. A. (2018). Black women and their struggle for survival: A study in Toni Morrison's and Alice Walker's novels through various perspectives: A narrative review. Opción, 34(85).

Sharma, J. K. (2011). Thematic concerns in the novels of Toni Morrison. Researchers World, 2(3), 173-176. 
Any, J. S. (2016). Exploring postcolonial ecofeminism in Kamala Markandaya's Nectar in a Sieve and Toni Morrison's The Bluest Eye (Doctoral dissertation, East West University).

Babamiri, N. S. (2014). Deformed motherhood in the Bluest Eye by Toni Morrison. Journal of Academic and Applied Studies (Special Issue on Applied and Humanity Sciences), 4(12), 1-12.

Beauvoir, S. D. (1989). The Second Sex. New York: The Vintage Books.

Belsey, C. (2005). Textual analysis as a research method. In E. G. Griffin, Research Methods for English Studies (pp. 157-174). Edinburgh: Edinburgh University Press.

Sarulatha, D., \& Geetha, N. (2015). Quest for identity in Toni Morrison's The Bluest Eyes. Asia Pacific Journal of Research, 33(1), 174-177.

Heinart, J. L. J. (2009). Novel of education: Bildungsroman and The Bluest Eyes. In N. P., Narrative Conventions and Race in the Novels of Toni. New York: Routledge.

Laksmitarukmi, A. (2017). Patriarchal viewpoint on women and nature: An ecofeminist reading on Dan Brown's Inferno (Doctoral dissertation, Sanata Dharma University).

Mbalia, D. D. (1991). The Bluest Eye: The need for racial approbation. In N. P., Toni Morrison's Developing Class Consciousness (p. 28). Selinsgrove: Susquehanna University Press.

Morrison, T. (1970). The Bluest Eyes. London: Vintage.

Tyson, L. (2006). Feminist criticism. In L. Tyson, Critical Theory Today: A Use-Friendly Guide (Second Edition ed., pp. 83-130). New York: Routledge. 